\title{
Critical Thinking as a Nourishing Interface to EFL Context in Higher Education
}

\author{
Elcin Petek ${ }^{1}$ \\ ${ }^{1}$ School of Foreign Languages, Cukurova University, Adana, Turkey \\ Correspondence: Elcin Petek, School of Foreign Languages, Cukurova University, 01330, Adana, Turkey. E-mail: \\ petekelcin@gmail.com
}

Received: November 7, 2017

Accepted: January 30, 2018

Online Published: April 23, 2018

doi:10.5539/ies.v11n5p1

URL: https://doi.org/10.5539/ies.v11n5p1

\begin{abstract}
As one of the renowned learning and innovation skills of 21 st century, critical thinking (hereafter CT) has been studied in various fields of education. Contrary to expectations, the emphasis on the mutual link between CT and language learning in tertiary education is newly flourishing. That being the case, the awareness of English as a Foreign Language (hereafter EFL) learners regarding this close connection and how it affects their perceived language learning potential should be inquired and increased. Drawing on such need, this paper reports on the investigation of an action research implementation and its effects on the perceptions of EFL learners over a ten week period of CT integrated practice. Qualitative and quantitative analysis of the data collected through two CT tasks, open-ended questionnaires, and semi-structured interviews based on learners' logs revealed an unequivocal influence on the perspectives of EFL learners towards CT and language learning. The implementation also helped the learners improve their thinking and language skills.
\end{abstract}

Keywords: critical thinking, EFL context, higher education

\section{Introduction}

\subsection{CT as a Concept}

The integration of hi-tech devices into our daily lives has a short but very rapidly expanding history. This has pushed humanity to develop sophisticated skills to deal with the information boost gaining momentum with the invention of a new communication tool each day. Influenced by this fact, today's learners should not be ignorant but be aware that learning to think critically is now inescapably on a par with many other learning skills to survive in a global village (Trilling \& Fadel, 2009).

Besides, many other capabilities including the ability to communicate in at least a commonly spoken foreign language, thinking flexibly and cooperating with others are the sine qua non of the new era. Added to the qualities above, drawing sound conclusions out of situations to make informed decisions - another component of CT - lead to a more innovative attitude in the 21st century work place and society (Trilling \& Fadel, 2009; Kivunja, 2014). That is why enhancing the development of graduates with CT skills is vital in universities (Stupple et al., 2017).

Despite the commonly acknowledged importance of CT in the academia, unfortunately majority of the students are deprived of a sound explanation or they are filled with misconceptions regarding what CT really entails (Stupple et al., 2017). As a matter of fact, it is no surprise they cannot show the related traits in most of the academic courses. Thus, clarifying and deepening the learners' perceptions on what CT encompasses is a prerequisite before asking them to reveal the characteristics of a critical thinker.

When looked into the CT-related literature, we can see that prominent scholars proposed various defining aspects so far for CT. These ranged from analytic thinking which is based on reasoning with a reflective attitude (Paul and Elder, 2014; Ennis, 2013) to purposeful, self-regulatory judgement (Facione, 2013, Halpern, 2003). Accepted as one of the buzz words of 21st century education, CT remains hard to define since it is prone to multiple interpretations. From this point of view, one of the latest and comprehensive definitions proposed by Paul and Elder (2014) was taken as a framework for the current study. According to this definition, a well-cultivated critical thinker:

- raises vital questions and problems, formulating them clearly and precisely; 
- gathers and assesses relevant information, and effectively interprets it;

- comes to well-reasoned conclusions and solutions, testing them against relevant criteria and standards;

- thinks open-mindedly within alternative systems of thought, recognizing and assessing, as need be, their assumptions, implications, and practical consequences; and

- communicates effectively with others in figuring out solutions to complex problems (p. 4).

In addition to these, another framework provided by Ennis (2011) suggesting being mindful of others' perspectives and alternatives in solving a problem or a controversial issue among the featured qualities of a critical thinker was a complementary reference point in addressing $\mathrm{CT}$ as a concept in the study.

\subsection{CT in Turkish Language Education System}

In Turkey, the New English Language Curriculum proposed by the Ministry of National Education (MoNE) explicitly refers to the development and demonstration of CT skills in language classes (MoNE, 2013). However, when the latest results of Programme for International Student Assessment (PISA) are taken into consideration, the decline in such skills as problem solving, creative and critical thinking are obviously acknowledged on the part of Turkish students (OECD, 2016). The aforementioned deterioration in higher order thinking skills of Turkish learners was also reported by a nationwide observational study on the implementation of higher order thinking skills in English teaching classes of Turkey (British Council, 2015).

Apparently, CT has not received the attention it deserved in primary, secondary and higher education in Turkey so far (Doğanay et al., 2007; Doğanay \& Ünal, 2006). This in turn has led to the bulk of memorization-addicted generations who are deprived of an ability to make meaning out of what they learn at school. Such a superficial attitude towards learning is also existent in the foreign language teaching and learning case (Petek \& Bedir, 2015). Oftentimes, students suffer from not being able to communicate in English, which is the commonly taught foreign language in Turkey despite many years of exposure to English classes.

Hence, if learners are given a chance to develop self-awareness regarding their assumptions, prejudices and values by means of language classes, they can not only gain a new point of view but also benefit from the use of CT to promote their language skills (Üstünlüoğlu, 2004). After all, language classrooms are among the best places to activate ideas, question the culture-bound habits and acquire new perspectives due to an array of materials and methods employed (Kabilan, 2000). Thus the value of CT in the foreign language classrooms and how they mutually improve each other should be accentuated through more practice oriented research.

\subsection{Research Rationale}

A multitude of studies have been conducted on the CT levels or tendencies of learners at the national and international arena in different fields of education (e.g. Kökdemir, 2003; Fidanc1 et al., 2012; Alagözlü, 2007; Doğanay et al., 2007; Sağlam \& Büyükuysal, 2013; Rusdi \& Umar, 2015; Marin \& Halpern, 2011; Zetriuslita et al., 2016). The commonly addressed finding was that learners had either moderate or low levels of CT. This finding reveals the scarcity of attempts to ameliorate learners' CT development. It is now widely accepted that thinking critically has a strong potential to enhance the academic success of a learner subjectwise if given appropriate training (Renaud and Murray, 2008). On the other hand the research on the use of CT in EFL classes in higher education are scarce (For example; Meiramova, 2017; Pineda, 2004; Klimoviene et al., 2006; Quintero, 2012). Since improvement of CT skills is expected to have a positive influence on the foreign language skills of learners (Stupple et al., 2017), the cultivation of awareness on the constructive relationship between CT and language learning is also an issue to be stressed out. Although the definitions are abundant, learners are deprived of a thorough explanation as regards the components of $\mathrm{CT}$ and this leads to an inability to develop such a skill when coupled with system-wide obstacles in education (Petek \& Bedir, 2015; Stupple et al., 2017). Such deprivation can partially be attributed to the lack of explicit CT-oriented instruction given to the individuals (Doğanay \& Ünal, 2006; Marin \& Halpern, 2011).

Admittedly, the need to embed $\mathrm{CT}$ as a higher order thinking skill into the teaching curriculum is increasing day by day (Ennis, 2013). Thus, it is crucial that students first develop a broad-enough notion of CT and experience its supportive role in advancing their language skills. At that point, the current study aimed to contribute to the literature by researching the effects of nurturing a group of tertiary level EFL learners' perceptions on the adjuvant role of $\mathrm{CT}$ in promoting foreign language learning. Such an attempt encompassed an explicit and systematic classroom-friendly training approach. Therefore, the study was shaped around four main research questions:

1) What are tertiary-level Turkish EFL learners' perceptions regarding CT before a CT integrated English instruction? 
2) What are tertiary-level Turkish EFL learners' perceptions regarding the relationship between CT and language learning before a CT integrated English instruction?

3) Do tertiary-level Turkish EFL learners' perceptions on CT improve through a CT integrated English instruction?

4) Do tertiary-level Turkish EFL learners' perceptions on the relationship between CT and language learning improve through a CT integrated English instruction?

\section{Methodology}

\subsection{Context and Participants}

Prior to the study, the researcher had been observing a lack of enthusiasm in students in terms of answering the questions or joining the activities that call for deeper thinking. On the other hand, when asked comprehension level wh- or yes/no questions, they jumped right into the answer without much consideration. When queried about the reason of such behavior, they generally attributed this to their low level of English which in fact was not the case since they were at level B1 according to Common European Framework of Reference (CEFR) for Languages (CoE, 2001) at the time. Another observation was that students were either impatient with each other's ideas when a discussion topic emerged or they complained about not being able to think of alternative answers on a question. Commonly mentioned in the literature, these handicaps led the researcher to the conclusion that first these attitudes should be changed via increasing awareness on the significance of CT for language learning and the vice versa.

The study was conducted at the School of Foreign Languages (SOFL) of Cukurova University in Turkey. The participants were a group of university students from various engineering departments, but they were primarily enrolled in the SOFL to learn English prior to their 4-year undergraduate education. The programme aimed to equip the students with both academic and general English communication skills so that they could survive in their English-medium departments later on. Thus, every class had at least two teachers one of which taught the course book, whereas the other one focused on the development of academic skills through reading, writing, listening, and speaking practice. The academic year, which lasted for eight months, was divided into four two-month blocks with three different levels (L) from L1 to L3 taking CEFR as the reference point. In this way, an L1 students' level of proficiency corresponded to A1 in CEFR after taking a placement exam at the beginning of the year. At the end of a full year receiving only English language instruction, the students were supposed to pass an integrated proficiency exam where they needed to prove their proficiency at a minimum level of B2. In the exam, they were required to express not only sufficient grammar and vocabulary knowledge but also the ability to interpret various reading and listening texts, and write on issues that call for higher order thinking.

The researcher collaborated with a group of $20 \mathrm{~L} 1$ class students ( 11 male, 9 female) whose ages ranged from 18 to 20 years old. Their level of English proficiency was around B1 at the time of the study given that they started to take the 10 week CT integrated language training in the third block. The participants were selected through convenience sampling, as the researcher was also the academic skills teacher of the class during the study.

\subsection{Data Collection}

To ensure the validity and the reliability of the study, multiple data collection tools were used for the study. These were composed of pre and post-questionnaires, two CT tasks, and semi-structured interviews based on learner logs.

\subsection{Implementation}

In search of an answer for the research questions, the researcher first asked the students to fill in an open-ended questionnaire made up of four questions and do two CT tasks, which had been piloted prior to the study. After analyzing the results, she compiled a series of collaborative critical thinking techniques and designed them according to the context-specific needs of the students (See Table 1). 
Table 1. Implementation period

\begin{tabular}{lll}
\hline Week & Implementation & Alloted Time \\
\hline 1 & $\begin{array}{l}\text { Pre-questionnaires, Pre CT tasks } \\
2\end{array}$ & $\begin{array}{l}\text { Discussion of the preliminary results with the students } \\
\text { Critical Reading (Module 1\&2) }\end{array}$ \\
3 & Critical Reading Role-Play (Module 3) & 1 class hour \\
4 & The Plus-Minus-Interesting Technique (Module 4) & 4 class hours \\
5 & The SEEI Technique (Module 5) & 4 class hours \\
6 & The Think-Pair-Share Technique (Module 6) & 4 class hours \\
7 & Six Thinking Hats (Module 7a) & 4 class hours \\
8 & Six Thinking Hats (Module 7b) & 4 class hours \\
9 & Overview and discussion with the students on the implementation & 4 class hours \\
10 & Post-questionnaires, Post CT tasks, Individual Semi-structured interviews & 4 class hours \\
\hline
\end{tabular}

As Table 1 shows, after sharing the preliminary results with the students, the implementation of the modules started. In Module 1\&2, the researcher encouraged a discussion atmosphere emanating from the learners' answers to the pre-questionnaire with an aim to increase their self-awareness on CT as a term. Subsequent to that, she had an introductory class on $\mathrm{CT}$ and critical reading via a ppt presentation. The session proceeded in a question/answer format. In Module 3, the learners were first given a short reading passage suited to their levels of English and asked to answer some questions that call for critical reading. After discussing the responses as a whole class, they were instructed to get into groups of four through a mini-grouping activity and assigned roles (leader, reporter, note-taker, and time keeper). Once the researcher clarified the mission of each role, she provided a scenario over which the groups were supposed to discuss and fill in an outline. At the end of the given time, the reporters of the groups were invited to announce the ideas of the group. Module 4 was shaped around the Plus-Minus-Interesting (PMI) technique developed by de Bono (1985a). After a short warm-up with visuals and questions, the researcher started a discussion on a controversial issue (e.g. Turkish government wants to make English the official second language of Turkey. What would be the plus, minus and interesting points of such a decision?). The learners were expected to fill in a chart in groups of three and then share their opinions with the class. Another technique reported to increase CT - the SEE-I - was adopted in Module 5. In SEE-I postulated by Nosich (2009) learners are given a concept in groups. Then they are supposed to State the concept in their own words, Elaborate on it to clarify the concept, Exemplify it through a daily life example, and finally illustrate it via an analogy, metaphor or visuals. In the current study, the researcher designed this module in a contest format. Each time she presented the groups with a word in English (e.g. freedom, friend etc.), she kept the time limited so that there was a winner group at the end. She presented 10 random words in total. The trick was to ask every group to read their findings and they would get a point according to a flexible democratic voting criterion. In Module 6, a collaborative thinking technique Think-Pair-Share (TPS) first proposed by Lyman (1981) was used. Learners were again given a scenario on a daily life problem to be solved. Then they were asked to think on it individually and with their pairs by filling in a chart. The last two modules (Module 7a \& 7b) were devoted to de Bono's (1985b) famous six thinking hats technique. In module $7 \mathrm{a}$, the learners were first asked to watch the video-clip of a song about poverty, and then do a fill-in the blanks activity about the lyrics as a warm-up. Later on, they were required to pick up a hat and think according to the instructions given on behalf of that specific color of the hat (e.g. The green hat wants you to think of the possible solutions to the problem of poverty in your country). Once they came up with enough ideas, the learners got into groups of six and pronounced their opinions depending on the hat they were wearing. The researcher repeated this technique in Module $7 \mathrm{~b}$ with another scenario on purpose to let the students experience the viewpoint of a different color of hat. In the week before the post data collection stage, there was a wrap-up session on the techniques covered so far and a whole class reflection activity. The final week was allotted to the post-data collection.

At least four class hours were devoted to each module because the techniques had a dual mission to stimulate both critical thinking and language learning skills of the students since all the materials and the way of communication was in English during the implementation. Meanwhile, the students were completing learner logs right after each module where they reflected on what they liked, disliked about the lesson and what learning perspective they acquired through that specific lesson.

At the post-stage, the students first completed the CT tasks again, hence filled in an open-ended post-questionnaire which was composed of five questions.. Based on the results, the researcher tried to gain more insight by 
conducting semi-structured interviews with ten randomly selected students in the light of their learning logs. Like other means of data collection in this study, interviews were also carried out in Turkish to allow participants to better verbalize their thoughts. They were audio recorded, transcribed verbatim, and translated into English with the proofreading of a language teaching expert.

\subsection{Data Analysis}

The collected data were analyzed under two main headings: a) CT Tasks, b) Pre and Post questionnaires. These findings were supported with the extracts from the interviews as a third dimension to the study. The CT tasks were analyzed quantitatively using descriptive statistics. Then, the answers to the questionnaires were scrutinized to thematic analysis by grouping similar and recurring responses under broader themes. In qualitatively dominant studies, thematic analysis is highly preferred to make the data more interpretable (Creswell, 2008). In doing so, the researcher received help from another expert in the field of English Language Teaching to read the answers closely and code the themes to obtain a general understanding of the data.

\subsection{Credibility of the Study}

Through examining the data sets which were triangulated, the researcher and the accompanying expert in data analysis realized correspondence across the emerging topics which assured the validity and the reliability of the present study. Furthermore, the occurrences reported in learners' logs were taken into consideration to confirm the findings. At the end of the implementation, some of the students were invited for member checking by going over the responses given to pre and post questionnaires. They agreed with the conclusions drawn from the data. It is important to note that the researcher also consulted with another expert from the field of teacher education to review the questions for pre and post questionnaires, and learner logs in addition to data collection procedures, and analysis for increasing external validity. Meanwhile, the researcher had informed the students about the content of the study and got their written consents by warranting that they could withdraw from the study at any point upon request. She assured the students that pseudonyms would be used instead of their names while highlighting striking points in the study.

\section{Results and Discussion}

\subsection{CT Task Analysis Results}

The first stage of the research was the data collected through two CT tasks. In the first CT task, the participants were presented with a scenario where two students were expected to comment on a sentence without being given any other clues. After reading the scenario, the participants were asked to pick the student who had a critical thinking attitude.

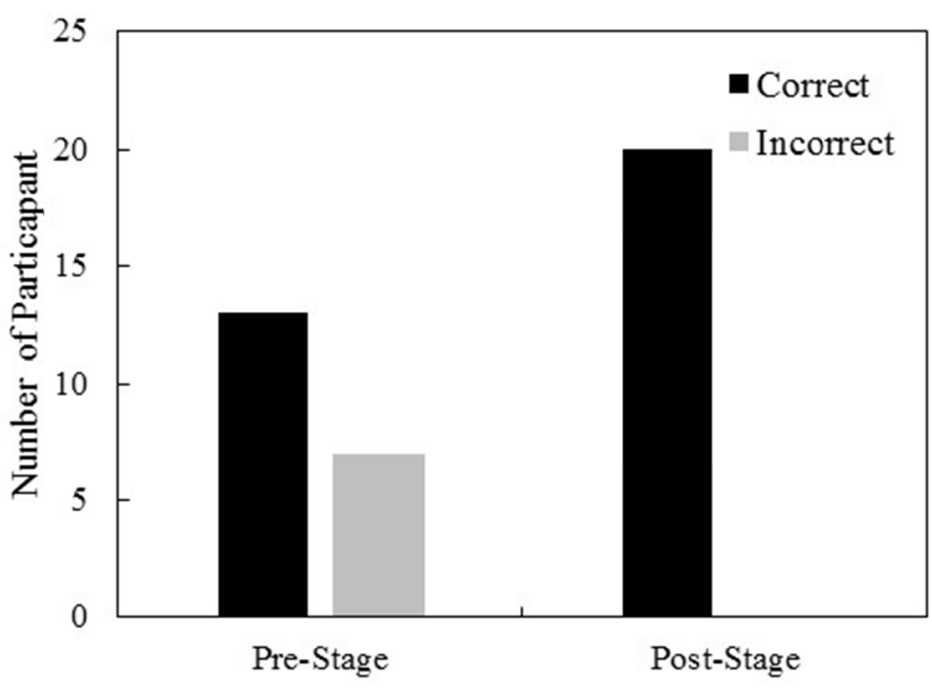

Figure 1. Responses to Task 1-pre and post stages

Figure 1 reveals that more than half of the participants $(\mathrm{N}=13)$ gave an incorrect answer during the pre-stage, whereas all of them could spot the real critical thinking student in the scenario during the post-stage. Similarly, CT task 2 was composed of another scenario where an English teacher required her two students to write about the 
"characteristics of a good friend". Upon reading the two students' descriptions, the participants were expected to pick the student who wrote with a critical perspective. The results are shown in Figure 2.

As seen in Figure 2, while more than half of the participants $(\mathrm{N}=12)$ could not detect the correct answer in the pre-stage, a vast majority $(\mathrm{N}=18)$ could tell right from wrong in the post-stage. The developmental results were in line with three other studies that made use of different CT tasks to track students' CT development at the perceptual and cognitive level (Klimoviene et al., 2006; Pineda, 2004; Quintero, 2012). In their studies, the researchers employed a series of CT techniques/activities to raise awareness in EFL learners and assessed their perception through different CT tasks. While the ratio of correct answers given to the tasks was relatively lower in the pre-stages of the studies, there was a tremendous increase in the participants' ability to diagnose the correct answer in the post-stages.

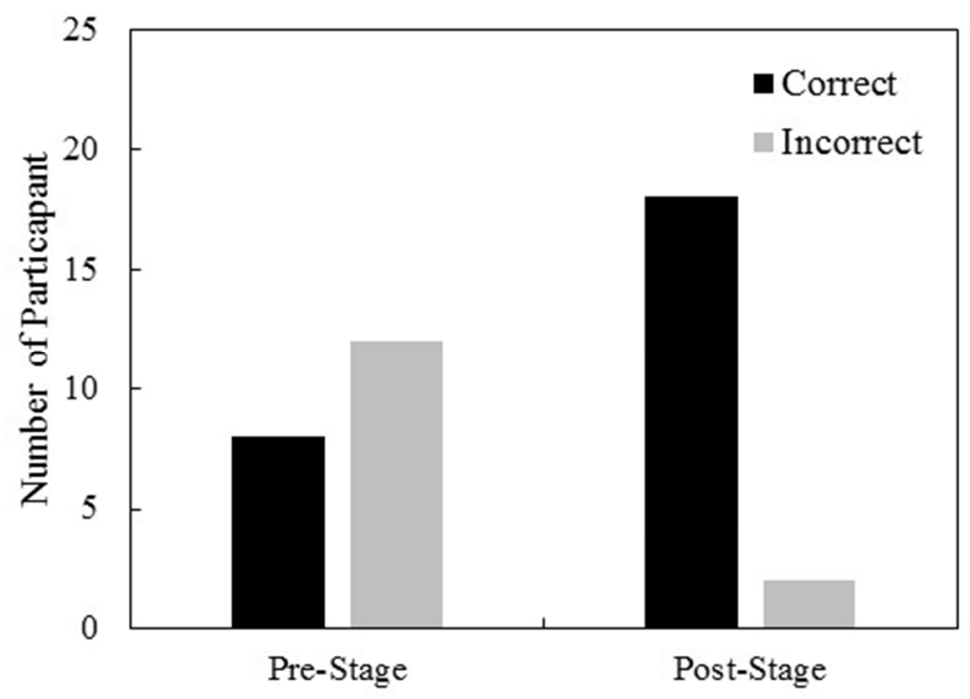

Figure 2. Responses to Task 2-pre and post stages

\subsection{Pre and Post Questionnaire Results}

In order to gain a deeper understanding of the participants' perspectives, they were first asked to define their conceptions of CT during the pre and the post interviews. Table 2 reveals the frequency of the emerging themes in response to the first question for pre-stage participants.

Table 2. Emerging themes related to interview Q1-pre stage

\begin{tabular}{lc}
\hline Pre-Stage & Number of Students \\
\hline Looking at the good and the bad sides of an issue & 1 \\
Fault finding & 4 \\
No idea & 7 \\
Questioning & 5 \\
Considering other's perspectives & 2 \\
Adjusting an issue subjectively & 6 \\
Total & 25 \\
\hline
\end{tabular}

As seen in Table 2, various themes were mentioned in both stages. Although many participants were able to describe some true characteristics of CT in the pre stage such as looking at the good and the bad sides of an issue $(\mathrm{N}=6)$, questioning issues/events $(\mathrm{N}=3)$, considering others' perspectives $(\mathrm{N}=2)$, another group perceived it as fault finding $(\mathrm{N}=4)$, and evaluating an issue subjectively $(\mathrm{N}=2)$ which were far from the targeted meanings in this context. Furthermore, the fact that another amount of participants $(\mathrm{N}=3)$ had no idea regarding the concept revealed a deficiency. The same question was posed to the participants in the post-stage as well. 
Table 3. Emerging themes related to interview Q1-post stage

\begin{tabular}{lc}
\hline Post-Stage & Number of Students \\
\hline Considering other's perspectives & 1 \\
Looking at the good and the bad sides of an issue & 5 \\
Rationalistic (Reason and result) & 8 \\
Evaluating an issue objectively (being unprejudiced) & 5 \\
Decision making based on evidence & 6 \\
Total & 25 \\
\hline
\end{tabular}

As Table 3 displays, at the end of the study, it was clear that all the participants' perceptions of CT were reshaped. A great majority $(\mathrm{N}=14)$ described it as considering others' perspectives followed by other true characteristics of CT such as looking at the good and the bad sides of an issue $(\mathrm{N}=6)$, rationalistic thinking $(\mathrm{N}=5)$, evaluating an issue objectively $(\mathrm{N}=5)$, and decision making based on evidence $(\mathrm{N}=2)$. A similar result was obtained in another study by Klimoviene et al. (2006) where the majority among the 90 students who were enrolled in a Bussiness English class was able to show the characteristics of CT in the face of related tasks after a CT oriented training which implied an increase in their awareness. Needless to say, the participants declared feeling content with the training they received on $\mathrm{CT}$ in that study.

For the current study, the change in perception was also highlighted in the interviews. It is seen in Extract 1 that participant B emphasized a very constructive effect of such training on their concept of CT and how it is reflected in their daily life:

B: I used to think criticizing and CT as the same things, but now I know CT is more about respecting others' perspectives. My reactions towards an opposing view were harsher before this training, but now I am more open to new ideas because the other person may have seen something that I cannot readily see. I also question more before accepting an idea as it is.

Likewise, participant $\mathrm{C}$ confessed the fact that they misperceived the meaning of $\mathrm{CT}$ prior to the implementation. They also declared the expanding impact of $\mathrm{CT}$ in their world knowledge:

C: I thought of CT as a negative way of thinking like criticizing, but I later realized that $\mathrm{CT}$ is more about looking at both the good and the bad sides. Brainstorming in the activities helped me broaden my vision. For example, I did not know much about New York, but learnt new things from my friends.

The second interview question was meant to obtain the participants' perceptions on the connection between CT and language learning before and after the training implementation.

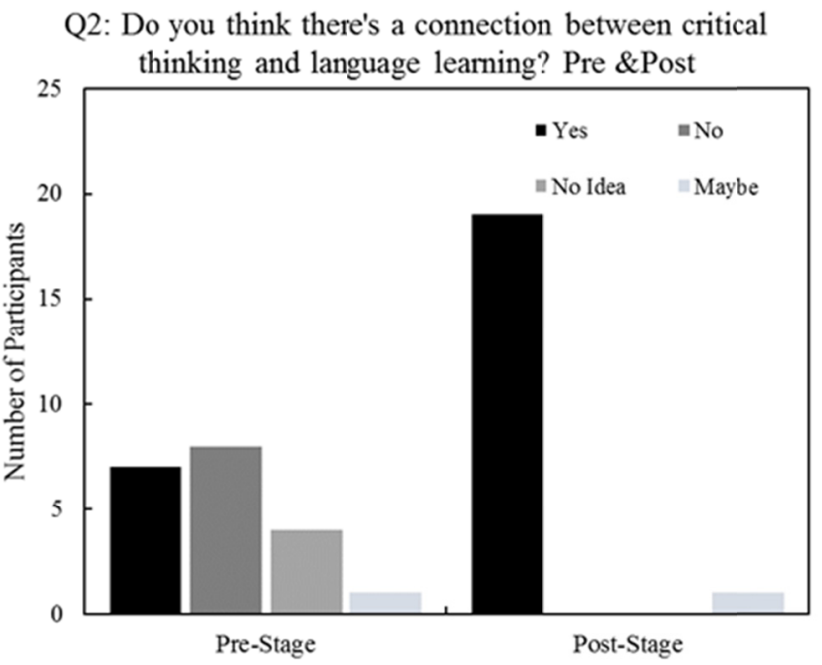

Figure 3. Change in responses to interview Q2-pre and post stages 
Q3: Do you think critical thinking can be improved in a

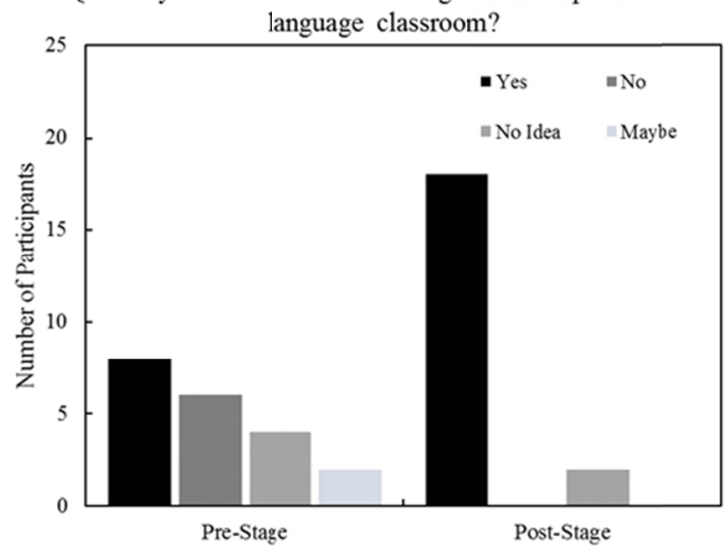

Figure 4. Change in responses to interview Q3-pre and post stages

As shown in Figure 3, even though the majority of the participants could not think of a connection $(\mathrm{N}=8)$ at the beginning, nearly all of them $(\mathrm{N}=19)$ mentioned a link between the two at the end of the implementation. With regard to that, the third interview question queried whether there was a change in the participants' perceptions towards the constructive role of learning a language on the development of CT.

It is clear in Figure 4 that most of the participants thought CT can be improved in a language classroom $(\mathrm{N}=8)$ but a considerable amount disagreed $(\mathrm{N}=6)$ and there were some hesitant answers $(\mathrm{N}=4)$ in the pre-stage. After the training, almost all participants $(\mathrm{N}=18)$ were in favor of the constructive role of one for the other. Similarly, in a previous study (Quintero, 2012), the participants as EFL learners pronounced a promotive relationship between CT and language classroom environment.

The fourth interview question inquired the participants' perspectives on whether they thought CT could promote their language skills or not with two sub-dimensions.

Q4: Thinking critically helps my language skills improve.

Do you agree with this statement?

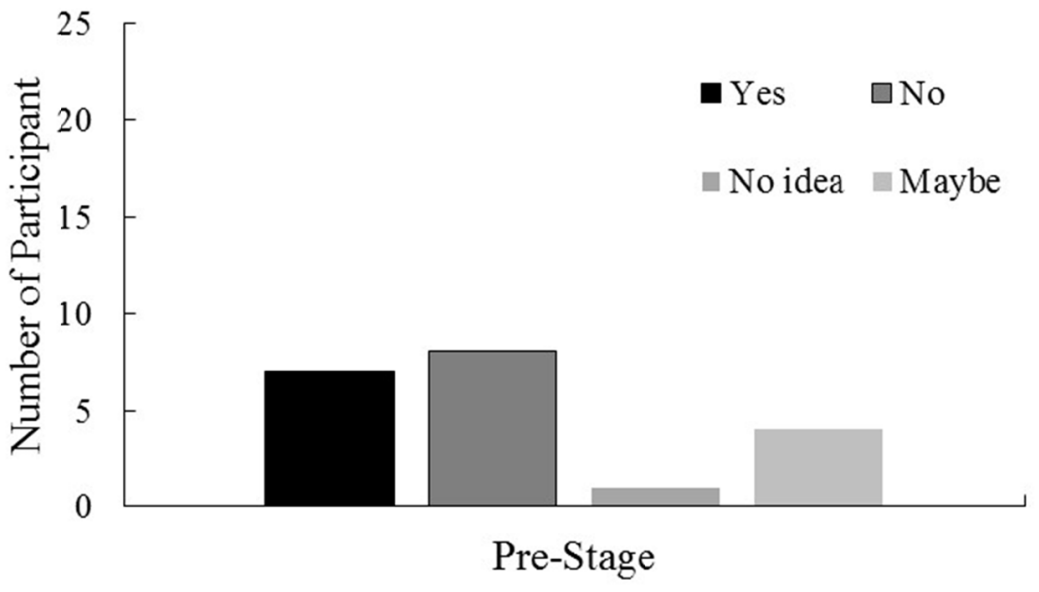

Figure 5. Responses to interview Q4-pre stage

It was indicated in Figure 5 that the leading answer to the question if they thought thinking critically helps their language skills improve was No $(\mathrm{N}=8)$ during the pre-stage. The question was rephrased in the post-stage to unravel their perceptions regarding the efficiency of the implementation. 


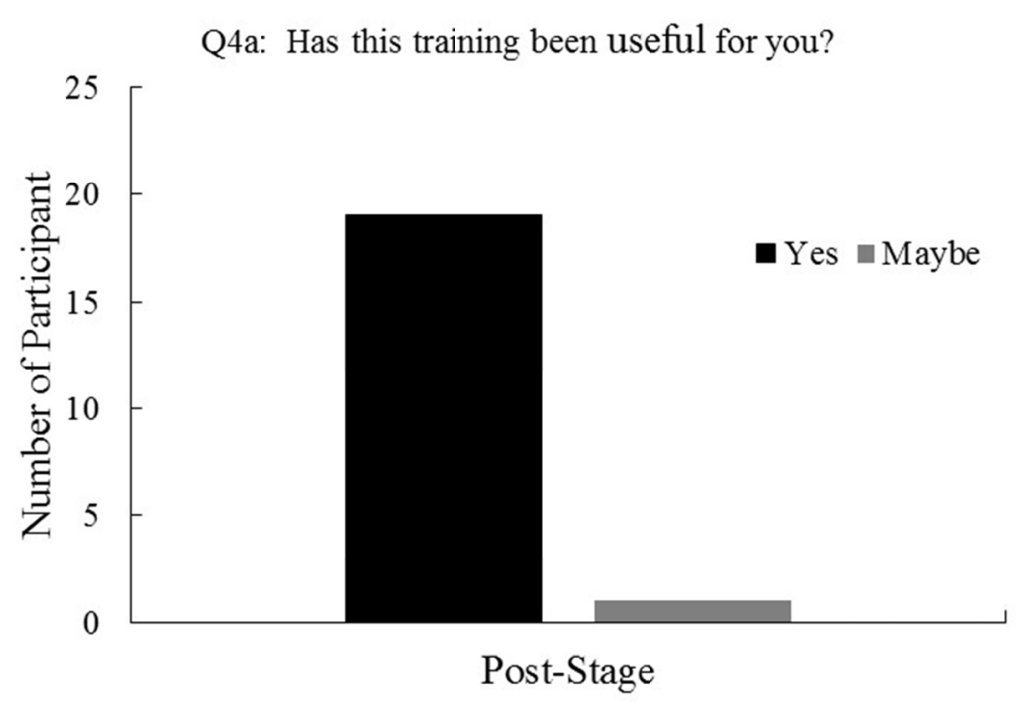

Figure 6. Change in responses to interview Q4a-post stage

Figure 6 displays that a great majority $(\mathrm{N}=19)$ agreed that such training practice supported their language production capacity due to ample practice through CT. The mastery of CT and its connection with good command of language skills were also confirmed by the findings of Klimoviene et al. (2006). A more recent study (Quintero, 2012) with a small group of upper-intermediate students of English announced increased motivation in students towards language learning coupled with advanced cognitive activity thanks to CT incorporation into EFL classes. A further question queried which of the language skills were nurtured out of this training.

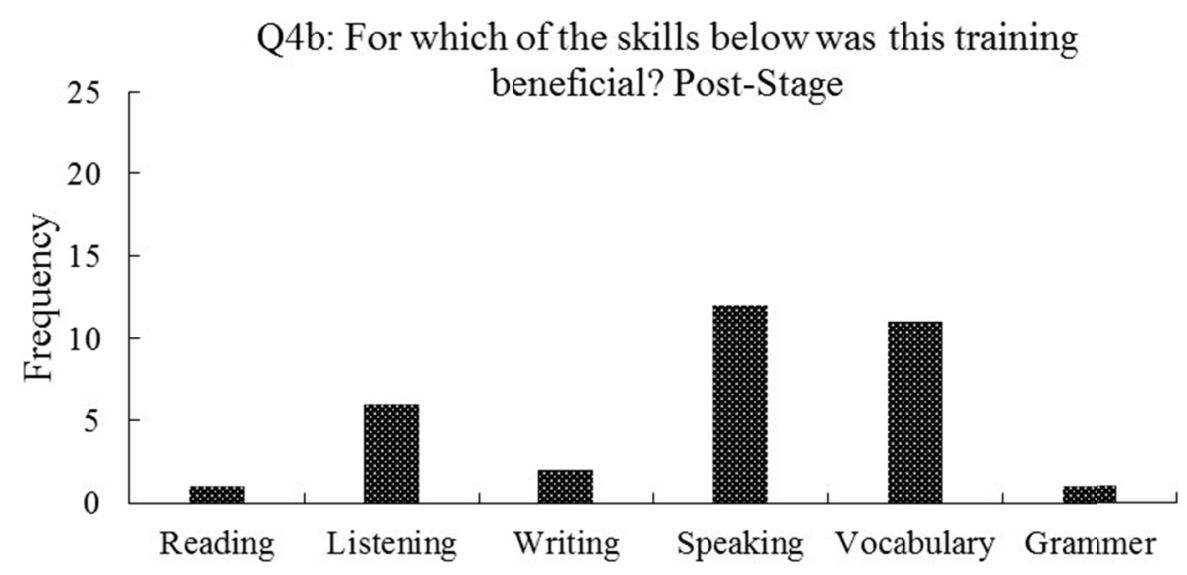

Figure 7. Responses to interview Q4b

Figure 7 clarifies the perception that such a training contributed to a variety of language skills; speaking skills $(\mathrm{N}=12)$ and vocabulary $(\mathrm{N}=11)$ development being the leading ones as well as listening skills $(\mathrm{N}=6)$ of the participants. The findings are in line with the results of a previous study (Pineda, 2004) where 32 Economics students of English with various proficiency levels were given a series of CT oriented activities. During and at the end of the study, it was observed that students' discursive competence was enriched besides improved lexical repertoire which evidently illustrates the constructive role of $\mathrm{CT}$ for foreign language development. 
In support of the fourth interview question, the striking extract from participant $\mathrm{N}$ demonstrated that this implementation had a positive influence on some specific language skills:

N: I perceived CT as a biased, negative thinking style, but later on I learnt that CT is more about gathering information before decision making. I used to focus on one perspective, but now I try to see an event from different perspectives. I take my mother's ideas into consideration more. I also began to understand in English more easily. I did a lot of speaking and listening practice.

Irrespective of the aforementioned findings above, the participants also reported increased awareness regarding themselves and the others coupled with enlarged vision on various topics which altogether contributed to their learning of English as given in the extracts below:

E: I did not want to hear the opposing views before, but now I look more openly. It kept me away from one-sided thinking. I did not only improve my English but also thought about various topics.

D: I realized that I may be prejudiced about people or things sometimes, but I started to look at things more objectively.

O: I think more deeply now. I empathize with others more and have realized the importance of such a skill because we lack this skill as a society.

G: I realized that I cannot produce many ideas when I think alone. During these activities, listening to my friends' ideas rang a bell in my mind and helped me to come up with more ideas.

T: I think of the topics we discussed in the class when I face a problematic situation or person in my daily life. I try to see the other sides. My awareness increased. I also started learning new words in English by associating them with the techniques we learnt.

In conclusion, the extracts implied a progressive change in the participants' attitudes towards daily life events and people around them throughout the implementation.

\section{Conclusion and Implications}

This study attempted to highlight the change in perceptions of EFL learners as regards the reciprocal relationship between $\mathrm{CT}$ and language learning through a CT integrated English instruction implementation. During the implementation, the lesson plans were specifically designed for improving learners' CT awareness by using English as a means of communication. Besides, learners' logs and interviews were beneficial to gather data as suggested by Alnofaie (2013). The findings indicated two main positive outcomes: 1.The learners' vision of CT in relation to language learning was gradually enlarged 2.Their reported language skills improved to a great extent due to multifaceted thinking on the issues in a foreign language. The results were in line with the reported findings of previous studies (Quintero, 2012; Klimoviene et al., 2006; Pineda, 2004; Meiramova, 2017) which displayed the constructive nature of $\mathrm{CT}$ in a foreign language classroom. Adding to this, the implementation helped the development of all language skills as it was conducted with a wholistic approach rather than adhering to only one or two language skills (Alnofaie, 2013). Besides, there was a developmental change in their $21^{\text {st }}$ century life skills such as responsibility taking, tendency to cooperate with others, advanced problem solving, increase in group consciousness without falling prey to sociocentrism, and patience with the opposing views (Kivunja, 2014; Yemenici, 2016).

It can be said that helping students gain the ability to think critically at various levels of education is among the significant duties of every education system (Doğanay et al., 2007). It is also much better when the latter level is designed to support the previous one in terms of fostering students' higher order thinking in an egalitarian way. Therefore, being familiar with what CT entails, and how to do it are some of the prerequisites to developing CT skills (Petek \& Bedir, 2015).

The findings of the study offer precious implications for EFL teaching/learning contexts as language classrooms are the ultimate sources to broaden the learners' visions in terms of CT skills (Kabilan, 2000):

- First of all, the results of the study partly indicate that Turkish education system does not sufficiently underline the importance of CT (Alagözlü, 2007) which may stimulate the emergence of more CT integration attempts at the national level. This study can also be taken as a contribution to the teaching of CT in EFL contexts world-wide by offering the promising outcome of a fruitful implementation process.

- Based on the reported benefits during and after the implementation, the study recommends incorporating more CT oriented practices into the EFL classrooms no matter what proficiency level the students are. Despite the claim in literature that students' foreign language proficiency can limit their CT ability (Manalo \& Sheppard, 2016), this study obviously revealed that foreign language classrooms can be among the best 
facilitators to CT when students view it as a means for conveying their thoughts on particular subjects rather than a grammatical entity. In a similar vein, thinking critically on all the tasks which were given in English during the implementation led to a more authentic atmosphere and thus provided an aim for students to communicate with each other in the foreign language. This in turn made it possible to expand their vocabulary knowledge along with other communication skills.

- Critical thinking is among the acclaimed objectives of National Education in Turkey; yet there is more to develop when the scarcity of classroom practices is taken into account (Atay, 2015). The role teachers play in developing such a complicated but rewarding skill is a directive one (Üstünlüoğlu, 2004) considering that bringing up critical thinkers is an effortful act rather than a self-generated one contrary to the mainstream thought (Paul and Elder, 2014). Thus, the study also brings the critical role of national and international language teacher educators to the fore who should allocate more space for such training initiatives in their agenda (Meiramova, 2017). This way, language teachers might be equipped with necessary knowledge, skills, and courage to infuse $\mathrm{CT}$ into their teaching syllabus

- Allegedly, CT may seem an already implicitly given skill in the curricula of higher education. Nevertheless, focusing on it more intentionally in academic contexts can help students develop a better notion of how to be a critical thinker and the benefits of the construct (Stupple et al., 2017; Doğanay et al., 2007). As a consequence, be it embedded in the readily taught language courses or presented as a specifically designed course, the study highlights the vitality of emphasizing CT explicitly (Meiramova, 2017; Manalo \& Sheppard, 2016; Marin \& Halpern, 2011) at higher education curriculum more clearly.

- The micro-level impact of the study also draws attention to the importance of embracing a culture of critical thinking (Alnofaie, 2013) at the institutional level in language education so that learners can transfer this skill into their academic development as well as language development more effectively.

\section{References}

Alagozlu, N. (2007). Critical thinking and voice in EFL writing. The Asian EFL Journal, 9(3), 118-136.

Alnofaie, H. (2013). A framework for implementing critical thinking as a language pedagogy in EFL preparatory programmes. Thinking Skills and Creativity, 10, 154-158. https://doi.org/10.1016/j.tsc.2013.09.002

Atay, D. (2015). Is critical thinking teachable in tertiary education? In Refresh: The Changing Role of Freshman English. In B. Rodrigues, B. Köktürk, H. S. Aydoğan, M. Güçeri, \& Z. İ. Önel, (Eds.). Sabancı University.

British Council. (2015). The state of English in higher education: A baseline study. TEPAV.

Council of Europe (CoE). (2001). Common European framework of reference for languages: Learning, teaching, assessment. Cambridge, England: Cambridge University Press. Retrieved August 27, 2013 from http://www.coe.int/t/dg4/linguistic/source/framework_en.pdf

Creswell, J. W. (2008). Educational research: Planning, conducting, and evaluating quantitative and qualitative research (3rd ed.). Pearson Merrill Prentice Hall.

de Bono, E. (1985a). De Bono's thinking course. London: Ariel Books.

de Bono, E. (1985b). Six thinking hats. London: Penguin.

Doğanay, A., \& Ünal, F. (2006). Eleştirel düşünmenin öğretimi. In A. Şimşek (Ed.). İçerik türlerine dayall ögretim. Nobel Yayın Dağıtım.

Doğanay, A., Akbulut-Taş, M., \& Erden, Ş. (2007). Assessing university students' critical thinking skills in the context of a current controversial issue. Educational Administration: Theory and Practice, 52, 511-546.

Ennis, R. (2011). A super-streamlined conception of critical thinking. Retrieved October 15, 2017 from http://faculty.education.illinois.edu/rhennis/SSConcCTApr3.html

Ennis, R. (2013). Critical thinking across the curriculum: The wisdom CTAC program. Inquiry: Critical Thinking Across the Disciplines, 28(2), 25-45. https://doi.org/10.5840/inquiryct20132828

Facione, P. A. (2013). Critical thinking: What it is and why it counts. Measured Reasons and the California Academic Press, Millbrae, CA.

Fidancı, B. E., Çınar, F. İ., Yıldız, D., Akar, F., Türk, A., Tuncer, S., ... Kökçe, B. D. (2012). Hemşirelik yüksek okulu öğrencilerinin eleştirel düşünme düzeylerinin ve eleştirel düşünmeyi etkileyen faktörlerin değerlendirilmesi. Gülhane Tip Derg 2012, 54, 35-39.

Halpern, D. (2003). Thought and knowledge: An introduction to critical thinking (4th ed.). Lawrence Erlbaum 
Associates

Kabilan, M. K. (2000). Creative and critical thinking in language classrooms. The Internet TESL Journal, 6(6). Retrieved October 10, 2017 from http://iteslj.org/Techniques/Kabilan-CriticalThinking.html

Kivunja, C. (2014). Do you want your students to be job-ready with 21st century skills? Change pedagogies: A pedagogical paradigm shift from Vygotskyian social constructivism to critical thinking, problem solving, and Siemens' digital connectivism. International Journal of Higher Education, 3(3), 81-91. https://doi.org/10.5430/ijhe.v3n3p81

Klimoviene, G., Urboniene, J., \& Barzdzuikiene, R. (2006). Developing critical thinking through cooperative learning. Studies about Languages, 9, 77-85.

Kökdemir, D. (2003). Belirsizlik durumlarında karar verme ve problem çözme [In Uncertainty conditions the decision making and problem solving] (Phd dissertation, Institute of social Sciences of Ankara University, Ankara).

Lyman, F. (1981). The Responsive Classroom Discussion. In A. S. Anderson (Ed.), Mainstreaming Digest (pp. 109-113). College Park, MD: University of Maryland College of Education.

Manalo, E., \& Seppard, C. (2016). How might language affect critical thinking performance? Thinking Skills and Creativity, 21, 41-49. https://doi.org/10.1016/j.tsc.2016.05.005

Marin, L. M., \& Halpern, D. F. (2011). Pedagogy for developing critical thinking in adolescents: Explicit instruction produces greatest gains. Thinking Skills and Creativity, 6, 1-13. https://doi.org/10.1016/j.tsc.2010.08.002

Meiramova, S. (2017). Applications of critical thinking research: Foreign language teaching in an intercultural context. The Online Journal of New Horizons in Education, 7(1), 24-36.

MoNE. (2013). English language curriculum for primary education (Grades from 2 to 8). Ankara.

Nosich, G. M. (2009). Learning to think things through: A guide to critical thinking across the curriculum (3rd ed.). Upper Saddle River, N.J.: Pearson Publishers (pp. 33-38).

OECD. (2016). PISA 2015 Results (Volume I): Excellence and Equity in Education. PISA, OECD Publishing, Paris. https://doi.org/10.1787/9789264266490-en

Paul, R., \& Elder, L. (2014). The miniature guide to Critical thinking: Concepts and tools (7th ed.). Foundation for Critical Thinking, Dillon Beach, CA.

Petek, E., \& Bedir, H. (2015b). Raising ELT students' awareness on the importance of critical thinking in language education. International Journal of Language Academy, 3(3), 11-22. https://doi.org/10.18033/ijla.255

Pineda, C. P. (2004). Critical thinking in the EFL classroom: The search for a pedagogical alternative to improve English learning. Íkala, revista de lenguaje y cultura, 9(15), 45-80.

Quintero, D. M. (2012). Critical thinking applied in communicative tasks: an innovative pedagogical practice in the EFL classroom through action research (Unpublished BA thesis). Technological University of Pereira, Pereira, Spain.

Rusdi, S. H., \& Umar, İ. N. (2015). Students' levels of critical thinking, supportive behaviors and types of questions in an online forum learning environment. Procedia-Social and Behavioral Sciences, 197, 1752-1758. https://doi.org/10.1016/j.sbspro.2015.07.232

Saglam, A. Ç., \& Buyukuysal, E. (2013). Critical thinking levels of senior students at education faculties and their views on obstacles to critical thinking. International Journal of Human Sciences, 10(1), 258-278.

Stupple, E. J. N., Maratos, F. A., Elander, J, Hunt, T. E., Cheung, K. Y. F., \& Aubeeluck, A. V. (2017). Development of the critical thinking toolkit (CriTT): A measure of student attitudes and beliefs about critical thinking. Thinking Skills and Creativity, 23, 91-100. https://doi.org/10.1016/j.tsc.2016.11.007

Trilling, B. \& Fadel, C. (2009). 21st Century Skills: Learning for Life in Our Times. Jossey-Bass, San Francisco, CA.

Üstünlüoğlu, E. (2004). Language teaching through critical thinking and self-awareness. English Teaching Forum, 42(3), 2-8.

Yemenici, A. (2016). Peace education: Training for an evolved consciousness of non-violence. All Azimuth, 5(1), 
5-42. https://doi.org/10.20991/allazimuth.167340

Zetriuslita, H., Ariawan, R., \& Nufus, H (2016). Students' critical thinking ability: Description based on academic level and gender. Journal of Education and Practice, 7(12), 154-164.

\section{Copyrights}

Copyright for this article is retained by the author(s), with first publication rights granted to the journal.

This is an open-access article distributed under the terms and conditions of the Creative Commons Attribution license (http://creativecommons.org/licenses/by/4.0/). 